\title{
Adaptation of the WHO maternal near miss tool for use in sub-Saharan Africa: an International Delphi study
}

\author{
Abera K. Tura ${ }^{1,2^{*}}$ (D), Jelle Stekelenburg ${ }^{3,4}$, Sicco A. Scherjon ${ }^{2}$, Joost Zwart ${ }^{5}$, Thomas van den Akker ${ }^{6}$,
} Jos van Roosmalen ${ }^{6,7}$ and Sanne J. Gordijn ${ }^{2}$

\begin{abstract}
Background: Assessments of maternal near miss (MNM) are increasingly used in addition to those of maternal mortality measures. The World Health Organization (WHO) has introduced an MNM tool in 2009, but this tool was previously found to be of limited applicability in several low-resource settings. The aim of this study was to identify adaptations to enhance applicability of the WHO MNM tool in sub-Saharan Africa.

Methods: Using a Delphi consensus methodology, existing MNM tools were rated for applicability in sub-Saharan Africa over a series of three rounds. Maternal health experts from sub-Saharan Africa or with considerable knowledge of the context first rated importance of WHO MNM parameters using Likert scales, and were asked to suggest additional parameters. This was followed by two confirmation rounds. Parameters accepted by at least 70\% of the panel members were accepted for use in the region.

Results: Of 58 experts who participated from study onset, 47 (81\%) completed all three rounds. Out of the $25 \mathrm{WHO}$ MNM parameters, all 11 clinical, four out of eight laboratory, and four out of six management-based parameters were accepted, while six parameters $(\mathrm{PaO} 2 / \mathrm{FiO} 2<200 \mathrm{mmHg}$, bilirubin $>100 \mu \mathrm{mol} / \mathrm{l}$ or $>6.0 \mathrm{mg} / \mathrm{dl}$, $\mathrm{pH}<7.1$, lactate $>5 \mu \mathrm{mol} / \mathrm{l}$, dialysis for acute renal failure and use of continuous vasoactive drugs) were deemed to not be applicable. An additional eight parameters (uterine rupture, sepsis/severe systemic infection, eclampsia, laparotomy other than caesarean section, pulmonary edema, severe malaria, severe complications of abortions and severe preeclampsia with ICU admission) were suggested for inclusion into an adapted sub-Saharan African MNM tool.
\end{abstract}

Conclusions: All WHO clinical criteria were accepted for use in the region. Only few of the laboratory- and management based were rated applicable. This study brought forward important suggestions for adaptations in the WHO MNM criteria to enhance its applicability in sub-Saharan Africa and possibly other low-resource settings.

Keywords: Maternal near miss, Delphi, Severe maternal morbidity, Sub-Saharan Africa, Global health

\section{Background}

In light of the global reduction in maternal mortality, assessments of severe maternal morbidity or maternal near miss (MNM) have become more common [1-3]. MNM is defined as a woman who nearly died but survived a complication that occurred during pregnancy, childbirth,

\footnotetext{
* Correspondence: a.k.tura@umcg.nl

${ }^{1}$ School of Nursing and Midwifery, College of Health and Medical Sciences, Haramaya University, Harar, Ethiopia

${ }^{2}$ Department of Obstetrics and Gynaecology (CB20), University of Groningen, University Medical Centre Groningen, Hanzeplein 1, 9700 RB Groningen, Netherlands

Full list of author information is available at the end of the article
}

or within 42 days of termination of pregnancy [3]. Different identification criteria for severe maternal morbidity have been applied in different contexts [4-6]. Application of the World Health Organization (WHO) MNM tool has become a standardized method to identify women at the severe end of the morbidity spectrum. This tool comprises three groups of criteria with clinical, laboratory and management based parameters that focus on the presence of organ dysfunction [6].

Though the WHO MNM tool has been widely used since its introduction including in sub-Saharan Africa [7-10], it also received criticism since several laboratory- 
based and some management-based criteria reflecting organ dysfunction turned out to be of limited relevance in resource-limited settings in sub-Saharan Africa [11, 12]. The need for more practical MNM criteria for use in low-income settings was previously noted [13] and the WHO Technical Working Group on Maternal Mortality and Morbidity classifications has indicated that an integrative module applicable to the local context for use in resource limited settings is under development [14]. Researchers have suggested possible adaptations $[11,12,15]$ at the expense of inter-study comparability.

Although there is evidence that several WHO MNM parameters are not applicable to low-income settings, there is a lack of well-founded alternative parameters formulated by experts with experience in such settings $[11,12,15]$. Lack of such uniform criteria prevents robust comparison studies of MNM. The aim of this study was to come to a consensus-based adaptation of the WHO MNM tool to enhance its applicability for use in low-income settings, particularly in sub-Saharan Africa.

\section{Methods}

We applied a three round Delphi study design. A Delphi is a structured group process in which a series of questionnaires is sent to a panel of experts who are asked to identify, rate or rank issues important to the subject under consideration [16]. It is a means of extracting opinion from a group of experts and is widely applied in medical, nursing and health services research [17-24]. We adopted a quasi-anonymous Delphi, in which each panel member was aware of the other participating members, but responses were kept anonymous and presented on a group level. In our opinion, it was important for members to be informed about the composition of the group in order to assign appropriate value to the panel. In every subsequent round, group responses were reported and instructions for completion of that round were provided. Questionnaire development, pre-testing, analysis and coordination were conducted by AKT and SJG. A Delphi steering committee consisting of all authors (AKT, SAS, JS, JZ, JvR, TvdA, and SJG) was established to coordinate the Delphi process, analyse comments and determine a priori criteria for consensus and termination of the study.

\section{Selection and recruitment panel of experts}

Expert panel members were selected if they authored an article on maternal near miss in sub-Saharan Africa [25] or if they were suggested by already selected authors. All experts were approached through email by introducing purpose of the study, its design, and a request to participate in the expert panel. We aimed to obtain wide coverage of experts with experience throughout subSaharan Africa and therefore no further selection was done after agreement for participation. After agreeing to participate, they were included in the first round and invited for subsequent rounds only if they completed the former round.

\section{The Delphi procedure}

Questionnaires were developed using LimeSurvey version 2.05+ (www.limesurvey.org) and sent with a unique, token secured link to participants using email. Three rounds of sequential online Delphi surveys were administered. Each round of Delphi was conducted over a three-week period with 2 to 3 months between rounds for analysis, questionnaire refinement and pilot testing. Email reminders were sent for nonrespondents approximately after 10 days followed by an additional two reminders. Members of the steering committee (JS, JZ, TvdA and JvR) did take part as experts within the survey.

We used the 2009 MNM tool that consisted of 25 parameters, as well as an additional 12 parameters from the literature $[4-6,11,26]$ in round 1 (Table 1). For each parameter, participants were asked to indicate their level of agreement on a 5-point Likert scale (ranging from $1=$ least important to $5=$ most important) as to whether that parameter would be important for identification of MNM in sub-Saharan Africa. A freetext field was also provided, inviting panel members to suggest additional parameters to be considered as criteria for MNM. Sociodemographic characteristics, professional background, country of work and experience of participants in sub-Saharan Africa were collected in round 1which was conducted in October 2015.

In round 2, which was conducted in December 2015, we grouped parameters from round 1 in to accepted, maybe accepted and rejected based on their median score of 5,4 , and $\leq 3$ respectively. A fourth group of suggested parameters was also constructed from parameters suggested for inclusion by participants in round 1 . These were presented to the panel for verification of the groups using a yes-no question. Consensus for inclusion of an item for use in an adapted 'sub-Saharan MNM tool' was defined a priori as at least $70 \%$ agreement. Level of agreement of at least $70 \%$ was used in several Delphi studies as level consensus [17, 18]. A parameter that failed to receive at least $60 \%$ would be excluded. Parameters with rates of agreement between $60 \%$ and $70 \%$ were brought back for voting again in round 3 . We asked the panel to indicate for every accepted parameter which definitions or cut off values should be considered by providing drafts of definitions and suggested cut-off points.

In round 3, conducted in May 2016, we included all parameters for which consensus was not reached for final voting. A list of parameters which reached 
Table 1 List of parameters presented for evaluation and suggested in the study

\begin{tabular}{|c|c|}
\hline Original parameters & Suggested parameters $(=14)$ \\
\hline \multicolumn{2}{|l|}{ WHO Parameters $(=25)$} \\
\hline $\begin{array}{l}\text { 1. Acute cyanosis } \\
\text { 2. Gasping } \\
\text { 3. Respiratory rate }>40 \text { or }<6 / \text { min } \\
\text { 4. Shock } \\
\text { 5. Oliguria non responsive to fluids or diuretics } \\
\text { 6. Failure to form clots } \\
\text { 7. Loss of consciousness lasting more than } 12 \mathrm{~h} \\
\text { 8. Cardiac arrest } \\
\text { 9. Stroke } \\
\text { 10. Uncontrollable fit/total paralysis } \\
\text { 11. Jaundice in the presence of pre-eclampsia } \\
\text { 12. Oxygen saturation }<90 \% \text { for }>60 \text { min } \\
\text { 13. PaO2/FiO2 }<200 \text { mmHg } \\
\text { 14. Creatinine }>300 \mu m o l / / \text { or }>3.5 \mathrm{mg} / \mathrm{dl} \\
\text { 15. Bilirubin }>100 \mu \text { mol/l or }>6.0 \text { mg/dl } \\
\text { 16. pH }<7.1 \\
\text { 17. Lactate }>5 \text { mEg/ml } \\
\text { 18. Acute thrombocytopenia ( }<50,000 \text { platelets/ml) } \\
\text { 19. Loss of consciousness and ketoacids in urine } \\
\text { 20. Use of continuous vasoactive drugs } \\
\text { 21. Hysterectomy following infection or haemorrhage } \\
\text { 22. Massive transfusion of blood or red cells }(\geq 5 \text { units) } \\
\text { 23. Intubation and ventilation for }>60 \text { min not related to anaesthesia } \\
\text { 24. Dialysis for acute renal failure } \\
\text { 25. Cardio-pulmonary resuscitation } \\
\text { Parameters from the literature ( }=12) \\
\text { 26. Uterine rupture } \\
\text { 27. Sepsis or severe systemic infection } \\
\text { 28. Eclampsia } \\
\text { 29. Laparotomy other than } C S \\
\text { 30. Pulmonary edema } \\
\text { 31. Admission to the ICU } \\
\text { 32. Diabetic Keto Acidosis } \\
\text { 33. Severe malaria } \\
\text { 34. Obstructed labour } \\
\text { 35. Severe anaemia } \\
\text { 36. Severe HIV related illnesses } \\
\text { 37. Uterine artery embolization }\end{array}$ & $\begin{array}{l}\text { 1. Severe abortion complications } \\
\text { 2. Failed tracheal intubation requiring anaesthetic reversal } \\
\text { 3. Maternal indication to terminate pregnancy } \\
\text { 4. Kussmaul respiration } \\
\text { 5. Severe dehydration } \\
\text { 6. Confusion } \\
\text { 7. Ketotic breath } \\
\text { 8. Acute kidney injury } \\
\text { 9. Uterine tamponade } \\
\text { 10. Ligation of internal iliac vessels } \\
\text { 11. Severe hypotension (SBP }<90 \mathrm{mmHg} \text { lasting }>60 \text { min) } \\
\text { 12. Pre-eclampsia with the presence of oliguria or respiratory disorder } \\
\text { 13. Severe PPH ( }>1000 \mathrm{ml} \text { of blood) within } 24 \mathrm{~h} \text { of delivery } \\
\text { 14. Severe pre-eclampsia with ICU admission }\end{array}$ \\
\hline
\end{tabular}

CS Caesarean Section, ICU Intensive Care Unit, HIV Human Immunodeficiency Virus, SBP Systolic Blood Pressure, PPH Postpartum haemorrhage

consensus for inclusion or exclusion were also presented for their information only. The cut-off point for inclusion remained $70 \%$. All responses were analysed using SPSS version 23.

\section{Results}

\section{Participants}

Of 102 experts invited for participation, 58 (56.9\%) agreed to participate. Fifty two out of $58(89.7 \%)$ completed round 1, 50/52 (96.2\%) round 2, and $47 / 49$ (95.9\%) all three rounds. One participant opted out from participation after round 2 due to internet connection problems. Twenty-two countries were represented by the expert panel, the majority from sub-Sahara Africa: one each from Belgium, Benin, Ghana, Kenya, Malawi, Mozambique, Norway, Rwanda, Sudan, Switzerland and United States of America; two from Italy; three each from Burkina Faso, Sweden, Uganda and United Kingdom; four each from Brazil, Ethiopia, Nigeria, South
Africa, and Tanzania; and seven from the Netherlands where the study was initiated.

Most experts were male $(n=40 ; 76.9 \%)$, obstetricians $(\mathrm{n}=40 ; 76.9 \%)$, and had a $\mathrm{PhD}$ degree $(n=28 ; 53.8 \%)$. The majority $(44 ; 84.6 \%)$ had more than 5 years of experience within their current position and 34 (65.4\%) had five or more years of work experience in subSaharan African settings. Four were members of the WHO working group on Maternal Mortality and Morbidity classifications who developed the WHO 2009 MNM tool [3, 6].

\section{First round}

Of the 37 parameters presented for evaluation, $21(56.8 \%)$ were rated as 'very important' (16 of 25 WHO parameters and 5 of 12 literature-based parameters). Twelve ( 6 of $25 \mathrm{WHO}$ and 6 of 12 literaturebased parameters) were rated as 'may be important' while 4 parameters ( 3 of $25 \mathrm{WHO}, 1$ of 12 literaturebased) were rated as 'unimportant'. Cardiac arrest, 
shock, loss of consciousness lasting more than $12 \mathrm{~h}$ and haemorrhage or infection leading to hysterectomy achieved greatest consensus with $>80 \%$ of experts rating these as 'very important'. Contrastingly, $\mathrm{PaO} 2 /$ FiO2 $<200 \mathrm{mmHg}$, lactate $>5 \mathrm{mEq} / \mathrm{ml}, \mathrm{pH}<7.1$ and uterine artery embolization received very low rates of agreement $(<22 \%)$ for use in the region. Specific levels of agreement for each parameter in round 1 are shown in Fig. 1. Several additional parameters $(n=31)$ were suggested for consideration by 19 panel members. All suggested parameters were collected by two authors (AKT and SJG) and presented to the steering committee for discussion. Parameters were discussed for their importance and were combined in case of overlap. Following the discussion among the Delphi steering committee, 14 parameters were summarized and reported back to the experts as 'suggested parameters' in round 2.

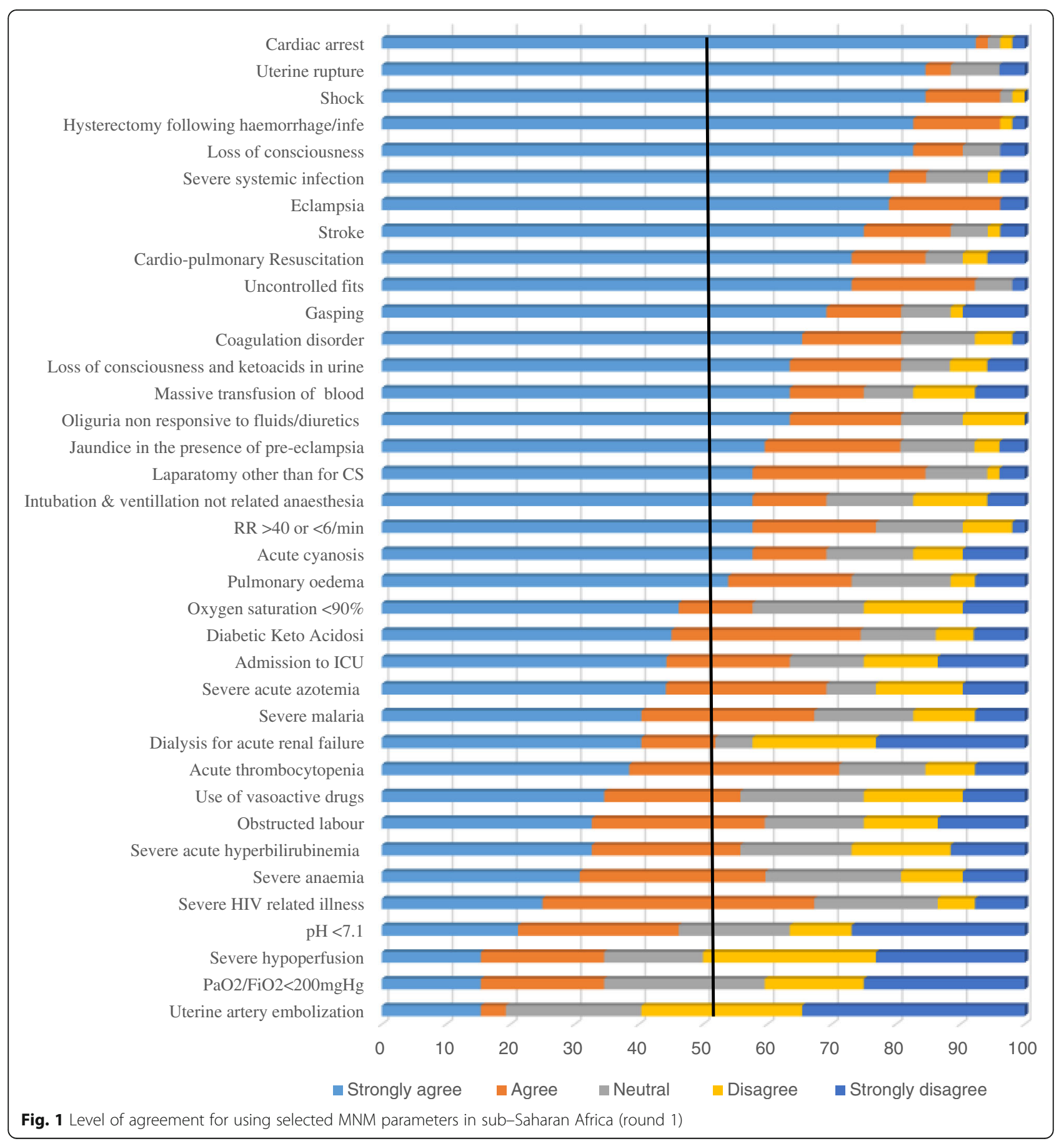




\section{Second and third rounds}

In round 2, consensus was reached to include 26 parameters (18 from WHO, 6 from the literature and two from suggested parameters. For accepted parameters, consensus ranged from $100 \%$ for shock and cardiac arrest to 71.7\% for severe pre-eclampsia with ICU admission. In this round, 15 other parameters were voted to be excluded. This includes four parameters from WHO $(\mathrm{PaO} 2 / \mathrm{FiO} 2<200 \mathrm{mmHg}, \quad \mathrm{pH}<7.1, \quad$ bilirubin $>100 \mu \mathrm{mol} / \mathrm{l}$ or $>6.0 \mathrm{mg} / \mathrm{dl}$, and lactate $>5 \mathrm{mEq} / \mathrm{ml}$ ), two from the literature based (obstructed labour and interventional radiology), and nine from the suggested parameters (Tables 2 and 3). Among rejected parameters consensus rates for inclusion of the MNM tool ranged from $6.5 \%$ for uterine artery embolization to $54.3 \%$ for obstructed labour. For 10 parameters, consensus was not reached for inclusion or exclusion. There was also no consensus on cut-off points for number of units of blood transfused to the mother as a proxy for major obstetric haemorrhage. The 10 parameters and suggested cut-off points for blood transfusion were therefore reported again in round 3 for rating.

In round 3, only one parameter (acute thrombocytopenia, platelets $<50,000 / \mathrm{ml}$ ) was accepted with a level of agreement of $72.3 \%$. Nine parameters including dialysis for acute renal failure and use of continuous vasoactive drugs from the WHO parameters were excluded. Other literature based parameters: admission to the intensive care unit, diabetic ketoacidosis, severe anaemia and severe HIV related illness were also rejected. Detailed level of agreement, the Delphi rounds and corresponding decisions is shown in Tables 2 and 3.

\section{Adapted sub-Saharan Africa MNM tool}

At the end of this Delphi exercise, 27 MNM parameters were accepted for use in sub-Saharan Africa. This includes 19 parameters from WHO 2009 parameters (11 out of 11 clinical, four out of eight laboratory-based, and four out of six management-based criteria). Additionally, eight parameters were accepted for MNM criteria in the region (six out of 12 literature based criteria and two from suggested parameters). These include seven clinical (eclampsia, pulmonary edema, ruptured uterus, severe complications of abortion, severe malaria sepsis/severe systemic infection and severe pre-eclampsia with ICU admission) and one management-based (laparotomy other than caesarean section) parameters. Consensus was reached on working definitions and cut-off values for the majority of the newly added parameters while the existing WHO definition was taken up for original parameters. Consensus was not reached for the number of units of blood to constitute MNM due to haemorrhage. Eighteen (38.3\%) experts suggested basing the need for blood transfusion, followed by $16(34 \%)$ and $14(29.8 \%)$ who opted using five and two units of blood transfusion respectively. The final set of 'sub-Saharan Africa MNM Tool' parameters with their respective definitions is shown in Table 4.

\section{Discussion}

To the best of our knowledge, this is the first study bringing together the opinions of a large group of experts concerning the construction of a feasible set of MNM criteria for use in low resource sub-Saharan African settings. The majority of the WHO MNM tool parameters were rated feasible for use in sub-Saharan Africa. On the other hand, our Delphi experts rated several laboratory and management-based parameters not to be feasible. On several clinical criteria, initially not included in the WHO MNM tool, consensus was reached and these are suggested to be added. Hence, we provided a framework of an adapted MNM tool with 27 parameters for use in sub-Saharan Africa.

We followed the structure of the existing WHO MNM tool to suggest inclusion or exclusion of parameters [6]. The adapted MNM parameters have the potential to serve as uniform adaptations and enable inter-study comparisons in the future. We followed recommended Delphi practices: reproducible participant criteria, a priori defined level of consensus for inclusion and exclusion of parameters, and a planned number of rounds $[27,28]$.

A majority of the WHO 2009 MNM parameters in general and the clinical criteria in particular were found to be acceptable criteria for use in sub-Saharan Africa. These results are in line with adaptations suggested in Rwanda [15], Tanzania [11], and Malawi [12].

Our results also favour inclusion of several clinical criteria, which were not part of the 2009 WHO MNM parameters. Such parameters were previously part of the recommendations by researchers who tried application of the tool in low-income settings [11, 12, 15]. Out of these eclampsia, ruptured uterus, and sepsis/severe systemic infection are classified as 'potentially life threatening complications' of pregnancy by WHO $[3,6]$. Inclusion of these potentially life threatening complications as additional parameters for MNM is supported by a recent study in maternity units in Latin America indicating that the likelihood of developing severe maternal outcomes (MNM \& MD) was high among cases with many these potentially life threatening complications [29]. A study from Malawi and other African countries that reported that these 'potentially life threatening complications' have high case fatality rates [30, 31].

In this study, only few of the laboratory- and management-based parameters were accepted into the sub-African MNM Tool. The use of laboratory, and 
Table 2 Rate of agreement on inclusion of selected MNM parameters for use in sub-Saharan Africa

\begin{tabular}{|c|c|c|c|c|c|c|c|c|c|c|c|}
\hline \multirow[t]{2}{*}{ Parameter } & \multicolumn{7}{|c|}{ Round $1(n=52)$} & \multicolumn{2}{|c|}{$\begin{array}{l}\text { Round 2 } \\
(n=50)\end{array}$} & \multicolumn{2}{|c|}{$\begin{array}{l}\text { Round } 3 \\
(n=47)\end{array}$} \\
\hline & $\begin{array}{l}\text { Strongly } \\
\text { Agree }\end{array}$ & Agree & Neutral & Disagree & $\begin{array}{l}\text { Strongly } \\
\text { disagree }\end{array}$ & Median & Decision & $\%$ & Decision & $\%$ & $\overline{\text { Decision }}$ \\
\hline 1. Cardiac arrest & 48 & 1 & 1 & 1 & 1 & 5 & Accepted & 100 & Accepted & - & - \\
\hline 2. Shock & 44 & 6 & 1 & 1 & 0 & 5 & Accepted & 100 & Accepted & - & - \\
\hline 3. Loss of consciousness lasting $>12 \mathrm{~h}$ & 43 & 4 & 3 & 0 & 2 & 5 & Accepted & 98 & Accepted & - & - \\
\hline $\begin{array}{l}\text { 4. Hysterectomy for haemorrhage or } \\
\text { infection }\end{array}$ & 43 & 7 & 0 & 1 & 1 & 5 & Accepted & 98 & Accepted & - & - \\
\hline 5. Stroke & 39 & 7 & 3 & 1 & 2 & 5 & Accepted & 92 & Accepted & - & - \\
\hline 6. Uncontrolled fits/total paralysis & 38 & 10 & 3 & 0 & 1 & 5 & Accepted & 96 & Accepted & - & - \\
\hline 7. Cardiopulmonary resuscitation & 38 & 6 & 3 & 2 & 3 & 5 & Accepted & 98 & Accepted & - & - \\
\hline 8. Gasping & 36 & 6 & 4 & 1 & 5 & 5 & Accepted & 92 & Accepted & - & - \\
\hline $\begin{array}{l}\text { 9. Failure to form clots/coagulation } \\
\text { disorder }\end{array}$ & 34 & 8 & 6 & 3 & 1 & 5 & Accepted & 96 & Accepted & - & - \\
\hline $\begin{array}{l}\text { 10. Oliguria non-responsive to fluids or } \\
\text { diuretics }\end{array}$ & 33 & 9 & 5 & 5 & 0 & 5 & Accepted & 92 & Accepted & - & - \\
\hline 11. Transfusion of blood & 33 & 6 & 4 & 5 & 4 & 5 & Accepted & 90 & Accepted & - & - \\
\hline $\begin{array}{l}\text { 12. Loss of consciousness \& ketoacidosis in } \\
\text { urine }\end{array}$ & 33 & 9 & 4 & 3 & 3 & 5 & Accepted & 90 & Accepted & - & - \\
\hline $\begin{array}{l}\text { 13. Jaundice in the presence of pre- } \\
\text { eclampsia }\end{array}$ & 31 & 11 & 6 & 2 & 2 & 5 & Accepted & 84 & Accepted & - & - \\
\hline 14. Acute cyanosis & 30 & 6 & 7 & 4 & 5 & 5 & Accepted & 92 & Accepted & - & - \\
\hline 15. Respiration rate $>40$ or $<6 / \mathrm{min}$ & 30 & 10 & 7 & 4 & 1 & 5 & Accepted & 94 & Accepted & - & - \\
\hline $\begin{array}{l}\text { 16. Intubation \& ventilation not related to } \\
\text { anaesthesia }\end{array}$ & 30 & 6 & 7 & 6 & 3 & 5 & Accepted & 92 & Accepted & - & - \\
\hline 17. Oxygen saturation $<90 \%$ for $\geq 60 \mathrm{~min}$ & 24 & 6 & 9 & 8 & 5 & 4 & $\begin{array}{l}\text { May be } \\
\text { accepted }\end{array}$ & $80 \cdot 4$ & Accepted & - & - \\
\hline 18. Creatinine $\geq 300 \mu \mathrm{mol} / \mathrm{l}$ or $\geq 3.5 \mathrm{mg} / \mathrm{dl}$ & 23 & 13 & 4 & 7 & 5 & 4 & $\begin{array}{l}\text { May be } \\
\text { accepted }\end{array}$ & 73.9 & Accepted & - & - \\
\hline 19. Dialysis for acute renal failure & 21 & 6 & 3 & 10 & 12 & 4 & $\begin{array}{l}\text { May be } \\
\text { accepted }\end{array}$ & $67 \cdot 4$ & $\begin{array}{l}\text { May be } \\
\text { accepted }\end{array}$ & 66 & Rejected \\
\hline 20. Acute thrombocytopenia $<50,000 / \mathrm{ml}$ ) & 20 & 17 & 7 & 4 & 4 & 4 & $\begin{array}{l}\text { May be } \\
\text { accepted }\end{array}$ & $69 \cdot 6$ & $\begin{array}{l}\text { Maybe } \\
\text { accepted }\end{array}$ & $72 \cdot 3$ & Accepted \\
\hline 21. Use of continuous vasoactive drugs & 18 & 11 & 10 & 8 & 5 & 4 & $\begin{array}{l}\text { May be } \\
\text { accepted }\end{array}$ & $67 \cdot 4$ & $\begin{array}{l}\text { May be } \\
\text { accepted }\end{array}$ & $61 \cdot 7$ & Rejected \\
\hline 22. Bilirubin $>100 \mu \mathrm{mol} / \mathrm{l}$ or $>6.0 \mathrm{mg} / \mathrm{dl}$ & 17 & 12 & 9 & 8 & 6 & 4 & $\begin{array}{l}\text { May be } \\
\text { accepted }\end{array}$ & $52 \cdot 2$ & Rejected & - & - \\
\hline 23. $\mathrm{pH}<7.1$ & 11 & 13 & 9 & 5 & 14 & 3 & Rejected & $21 \cdot 7$ & Rejected & - & - \\
\hline 24. $\mathrm{PaO} 2 / \mathrm{Fi} 2<200 \mathrm{mmHg}$ & 8 & 10 & 13 & 8 & 13 & 3 & Rejected & 18 & Rejected & - & - \\
\hline 25. Lactate $>5 \mathrm{mEq} / \mathrm{ml}$ & 8 & 10 & 8 & 14 & 12 & 2 & Rejected & $17 \cdot 4$ & Rejected & - & - \\
\hline 26. Uterine rupture ${ }^{a}$ & 44 & 2 & 4 & 0 & 2 & 5 & Accepted & 94 & Accepted & - & - \\
\hline 30. Sepsis or severe systemic infection ${ }^{a}$ & 41 & 3 & 5 & 1 & 2 & 5 & Accepted & 90 & Accepted & - & - \\
\hline 34. Eclampsia ${ }^{a}$ & 41 & 9 & 0 & 0 & 2 & 5 & Accepted & 88 & Accepted & - & - \\
\hline 28. Laparotomy other than $\mathrm{CS}^{\mathrm{a}}$ & 30 & 14 & 5 & 1 & 2 & 5 & Accepted & 78 & Accepted & - & - \\
\hline 27. Pulmonary edema ${ }^{a}$ & 28 & 10 & 8 & 2 & 4 & 5 & Accepted & 78 & Accepted & - & - \\
\hline 29. Admission to the ICU & 23 & 10 & 6 & 6 & 7 & 4 & $\begin{array}{l}\text { May be } \\
\text { accepted }\end{array}$ & 63 & $\begin{array}{l}\text { May be } \\
\text { accepted }\end{array}$ & 59.6 & Rejected \\
\hline 36. Diabetic Keto Acidosis ${ }^{a}$ & 23 & 15 & 6 & 3 & 4 & 4 & $\begin{array}{l}\text { May be } \\
\text { accepted }\end{array}$ & $65 \cdot 2$ & $\begin{array}{l}\text { May be } \\
\text { accepted }\end{array}$ & $61 \cdot 7$ & Rejected \\
\hline
\end{tabular}


Table 2 Rate of agreement on inclusion of selected MNM parameters for use in sub-Saharan Africa (Continued)

\begin{tabular}{|c|c|c|c|c|c|c|c|c|c|c|c|}
\hline \multirow[t]{2}{*}{ Parameter } & \multicolumn{7}{|c|}{ Round $1(n=52)$} & \multicolumn{2}{|c|}{$\begin{array}{l}\text { Round } 2 \\
(n=50)\end{array}$} & \multicolumn{2}{|c|}{$\begin{array}{l}\text { Round } 3 \\
(n=47)\end{array}$} \\
\hline & $\begin{array}{l}\text { Strongly } \\
\text { Agree }\end{array}$ & Agree & Neutral & Disagree & $\begin{array}{l}\text { Strongly } \\
\text { disagree }\end{array}$ & Median & Decision & $\%$ & Decision & $\%$ & Decision \\
\hline 33. Severe malaria ${ }^{a}$ & 21 & 14 & 8 & 5 & 4 & 4 & $\begin{array}{l}\text { May be } \\
\text { accepted }\end{array}$ & 73.9 & Accepted & - & - \\
\hline 31. Obstructed labour ${ }^{a}$ & 17 & 14 & 8 & 6 & 7 & 4 & $\begin{array}{l}\text { May be } \\
\text { accepted }\end{array}$ & $54 \cdot 3$ & Rejected & - & - \\
\hline 32. Severe anaemia ${ }^{a}$ & 16 & 15 & 11 & 5 & 5 & 4 & $\begin{array}{l}\text { May be } \\
\text { accepted }\end{array}$ & 69.6 & $\begin{array}{l}\text { May be } \\
\text { accepted }\end{array}$ & $61 \cdot 7$ & Rejected \\
\hline 35. Severe HIV related illnesses ${ }^{a}$ & 13 & 22 & 10 & 3 & 4 & 4 & $\begin{array}{l}\text { May be } \\
\text { accepted }\end{array}$ & 69.6 & $\begin{array}{l}\text { May be } \\
\text { accepted }\end{array}$ & $57 \cdot 4$ & Rejected \\
\hline 37. Interventional radiology ${ }^{a}$ & 8 & 2 & 11 & 13 & 18 & 2 & Rejected & $6 \cdot 5$ & Rejected & - & - \\
\hline
\end{tabular}

management-based parameters in low-income settings is more problematic due to lack of laboratory facilities and qualified health staffs in many settings [11, 12, 15].

Consensus was not reached regarding the number of units of blood for transfusion as a criterion for major obstetric haemorrhage. In our opinion it is slightly alarming that more than one in three (34\%) panel members suggested that postpartum haemorrhage does not become life threatening in sub-Saharan Africa until five units of blood are administered, given the serious lack of blood for transfusion. In many district hospitals, it is very rare to have five units of blood available for transfusion. This renders a definition of MNM based on a number of transfusions highly problematic [32]. Although we tried to overcome this by providing an option based on the need for blood transfusion had it been available, no consensus was achieved. We strongly feel that a criterion of five units would underestimate the magnitude of MNM in the region. Hence, from a pragmatic point of view, we suggest the use of at least two units of blood as a cut-off, taking into account lack of blood for transfusion in the region. A cut-off of two units was found effective previously $[11,12]$.

This study involved participation of international maternal health experts, including experts involved in the development of the 2009 WHO MNM tool, from 22 countries with considerable expertise in sub-Saharan Africa. The views of included experts expressed here, however, may differ from those who declined or did not participate and outcomes do not necessarily represent the views of individual participants. Most of our expert panel members were male obstetricians, which is a reflection of the experts working in sub-Saharan Africa. We do not expect that another composition of the experts based on gender or professional background would

Table 3 Suggested parameters and respective decisions in round 2 and round 3

\begin{tabular}{|c|c|c|c|}
\hline Parameter & $\begin{array}{l}\text { Round } 2 \\
\text { n(\% agree) }\end{array}$ & $\begin{array}{l}\text { Round } 3 \\
\text { n(\% agree) }\end{array}$ & Final Decision \\
\hline 1. Severe abortion complications & $36(78 \cdot 3)$ & - & Accepted \\
\hline 2. Failed tracheal intubation requiring anaesthetic reversal & 17(37.0) & - & Rejected \\
\hline 3. Maternal indication to terminate pregnancy & 13(28:3) & - & Rejected \\
\hline 4. Kussmaul respiration & 18(39.1) & - & Rejected \\
\hline 5. Severe dehydration & 14(30.4) & - & Rejected \\
\hline 6. Confusion & $18(39 \cdot 1)$ & - & Rejected \\
\hline 7. Ketotic breath & 17(37.0) & - & Rejected \\
\hline 8. Acute kidney injury & $22(47 \cdot 8)$ & - & Rejected \\
\hline 9. Uterine tamponade & 20(43.5) & - & Rejected \\
\hline 10. Ligation of internal iliac vessels & $22(47 \cdot 8)$ & - & Rejected \\
\hline 11. Severe hypotension (systolic BP < 90 mmHg lasting >60 min) & 28(60.9) & $21(44 \cdot 7)$ & Rejected \\
\hline 12. Pre-eclampsia with the presence of oliguria or respiratory disorder & $32(69 \cdot 6)$ & $30(63 \cdot 8)$ & Rejected \\
\hline 13. Severe PPH (loss of more than $1000 \mathrm{ml}$ of blood) within $24 \mathrm{~h}$ of delivery & 29(63.0) & $31(66.0)$ & Rejected \\
\hline 14. Severe pre-eclampsia with intensive care unit admission & $33(71 \cdot 7)$ & - & Accepted \\
\hline
\end{tabular}


Table 4 Adapted sub-Saharan Africa MNM tool

\begin{tabular}{|c|c|}
\hline WHO maternal near miss criteria & $\begin{array}{l}\text { sub-Saharan Africa maternal near } \\
\text { miss criteria }\end{array}$ \\
\hline \multicolumn{2}{|l|}{ Clinical criteria } \\
\hline Acute cyanosis & Acute cyanosis ${ }^{\text {a }}$ \\
\hline Gasping & Gasping ${ }^{b}$ \\
\hline Respiratory rate $>40$ or $<6 /$ min & Respiratory rate $>40$ or $<6 / \mathrm{min}$ \\
\hline Shock & Shock ${ }^{c}$ \\
\hline $\begin{array}{l}\text { Oliguria non responsive to fluids } \\
\text { or diuretics }\end{array}$ & $\begin{array}{l}\text { Oliguria non responsive to fluids or } \\
\text { diuretics }{ }^{d}\end{array}$ \\
\hline Failure to form clots & Failure to form clots ${ }^{\mathrm{e}}$ \\
\hline $\begin{array}{l}\text { Loss of consciousness lasting } \\
\text { more than } 12 \mathrm{~h}\end{array}$ & $\begin{array}{l}\text { Loss of consciousness lasting more } \\
\text { than } 12 \mathrm{~h}^{\mathrm{f}}\end{array}$ \\
\hline Cardiac arrest & Cardiac arrest \\
\hline Stroke & Stroke ${ }^{g}$ \\
\hline Uncontrollable fit/total paralysis & Uncontrollable fit/total paralysis ${ }^{\mathrm{h}}$ \\
\hline \multirow[t]{8}{*}{$\begin{array}{l}\text { Jaundice in the presence of } \\
\text { pre-eclampsia }\end{array}$} & $\begin{array}{l}\text { Jaundice in the presence of pre- } \\
\text { eclampsia }{ }^{i}\end{array}$ \\
\hline & Eclampsia $^{j}$ \\
\hline & Uterine rupture $^{k}$ \\
\hline & Sepsis or severe systemic infection \\
\hline & Pulmonary edema ${ }^{m}$ \\
\hline & Severe abortion complications ${ }^{n}$ \\
\hline & Severe malaria ${ }^{\circ}$ \\
\hline & $\begin{array}{l}\text { Severe pre-eclampsia with ICU } \\
\text { admission }\end{array}$ \\
\hline
\end{tabular}

Laboratory based criteria

Oxygen saturation $<90 \%$ for

$>60$ min

Oxygen saturation $<90 \%$ for

$>60$ min

$\mathrm{PaO} 2 / \mathrm{FiO} 2<200 \mathrm{mmHg}$

Creatinine $\geq 300 \mu \mathrm{mol} / \mathrm{l}$ or

$\geq 3.5 \mathrm{mg} / \mathrm{dl}$

Creatinine $\geq 300 \mu \mathrm{mol} / \mathrm{l}$ or $\geq 3.5 \mathrm{mg} / \mathrm{dL}$

Bilirubin $>100 \mu \mathrm{mol} / \mathrm{l}$ or

$>6.0 \mathrm{mg} / \mathrm{dl}$

$\mathrm{pH}<7.1$

Lactate $>5 \mathrm{mEq} / \mathrm{ml}$

Acute thrombocytopenia

( $<50,000$ platelets/ml)

Loss of consciousness and

ketoacids in urine

Management based criteria

Use of continuous vasoactive

drugs

Hysterectomy following infection or haemorrhage

Hysterectomy following infection or haemorrhage

Transfusion of $\geq 5$ units of blood Transfusion of $\geq 2$ units of red blood cells
Table 4 Adapted sub-Saharan Africa MNM tool (Continued)

\begin{tabular}{ll}
\hline WHO maternal near miss criteria & $\begin{array}{l}\text { sub-Saharan Africa maternal near } \\
\text { miss criteria }\end{array}$ \\
\hline $\begin{array}{l}\text { Intubation and ventilation for } \\
\geq 60 \text { min not related to }\end{array}$ & $\begin{array}{l}\text { Intubation and ventilation for } \\
\text { anaesthesia }\end{array}$ \\
$\begin{array}{ll}\text { Dialysis for acute renal failure } \\
\text { Cardio-pulmonary resuscitation not related to anaesthesia }\end{array}$ & $\begin{array}{l}\text { Cardio-pulmonary resuscitation } \\
\text { Laparotomy other than caesarean } \\
\end{array}$ \\
\hline
\end{tabular}

${ }^{a}$ Acute cyanosis is blue or purple colouration of the skin or mucous membranes due to low oxygen saturation

${ }^{\mathrm{b}}$ Gasping is a terminal respiratory pattern and the breath is convulsively and audibly caught

'Shock is persistent severe hypotension, defined as a systolic BP $<90 \mathrm{mmHg}$ for $\geq 60 \mathrm{~min}$ with a pulse rate at least 120 despite aggressive fluid replacement (>2 L)

${ }^{\mathrm{d}}$ Oliguria is urinary output $<30 \mathrm{ml} / \mathrm{h}$ for $4 \mathrm{~h}$ or $<400 \mathrm{ml} / 24 \mathrm{~h}$

${ }^{e}$ Failure to form clots can be assessed by the bedside clotting test or absence of clotting from the IV site after 7-10 min

LLoss of consciousness lasting $>12 \mathrm{~h}$ is a profound alteration of mental state that involves complete or near-complete lack of responsiveness to external stimuli. It is defined as a Glasgow Coma Scale $<10$ (moderate or severe coma) ${ }^{9}$ Stroke is neurological deficit of cerebrovascular cause that persists beyond $24 \mathrm{~h}$ or is interrupted by death within $24 \mathrm{~h}$

huncontrolled fits/total paralysis is refractory, persistent convulsions or status epilepticus

'Pre-eclampsia is defined as the presence of hypertension associated with proteinuria. Hypertension is defined as a BP of at least $140 / 90 \mathrm{mmHg}$ on at least two occasions and at least 4-6 $\mathrm{h}$ apart after the 20th week of gestation in women known to be normotensive beforehand. Proteinuria is defined as excretion of $300 \mathrm{mg}$ or more of protein every $24 \mathrm{~h}$. If 24 -h urine samples are not available, proteinuria is defined as a protein concentration of $300 \mathrm{mg} / \mathrm{l}$ or more $(\geq 1$ on dipstick) in at least two random urine samples taken at least 4-6 $\mathrm{h}$ apart

${ }^{\mathrm{j}}$ Eclampsia is diastolic $\mathrm{BP} \geq 90 \mathrm{mmHg}$ or proteinuria +3 and convulsion or coma

kUterine rupture is complete rupture of uterus during labour and/or confirmed later by laparotomy

'Sepsis or severe systemic infection is defined as a clinical sign of infection and 3 of the following: temp $>38^{\circ} \mathrm{C}$ or $<36^{\circ} \mathrm{C}$, respiration rate $>20 / \mathrm{min}$, pulse rate $>90 / \mathrm{min}, \mathrm{WBC}>12,000$

mPulmonary edema is accumulation of fluids in the air spaces and parenchyma of the lungs

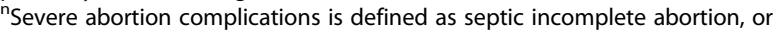
complicated gestational trophoblastic disease with anaemia

${ }^{\circ}$ Severe malaria is defined as major signs of organ dysfunction and/or high level parasitemia or cerebral malaria

influence the results. The use of the online system prevented bias towards strong voice [23, 28]. Participation was entirely voluntary, and all panel members were given the opportunity to withdraw from the survey at any stage.

Findings were limited by lack of arranging consultative meetings for parameters which were still undetermined in round 3. Consultative meetings were found to be effective in solving issues related to equivocal findings in other studies [17]. Arranging consultative meeting or video-conference was impossible due to financial and technological restrictions.

\section{Conclusion}

A majority of WHO MNM parameters were rated to be feasible for use in sub-Saharan Africa. Although the WHO MNM tool aims to enable comparisons between 
settings, and context-based adjustments of the tool may hamper inter-study comparability [6, 33], we feel that this aim becomes irrelevant unless the WHO tool is adjusted for use in low-resource settings where most MNM occurs [13]. In order to increase comparability of future studies, we recommend that researchers apply these adapted criteria for case selection. There is a need to assess specificity, sensitivity, and predictive value of the adapted tool compared to the WHO tool for use in sub-Saharan Africa or other low income settings [12, 34]. We hope that our results may be taken into account by WHO in their valued advocacy for studies into MNM, including comparisons. In addition, our results may feed into the Core Outcomes in Women's and Newborn Health Initiative (CROWN) [35] and our adapted tool may promote standardized outcome reporting in low-resource settings.

\section{Abbreviations}

CS: Caesarean section; ICU: Intensive care unit; MNM: Maternal near miss; PPH: Postpartum hemorrhage; WHO: World Health Organization

\section{Acknowledgments}

We thank the Netherlands Organization for International Cooperation in Higher Education (Nuffic) for funding this study in the form of a PhD grant. We would like to thank all experts who participated in this Delphi exercise (Adefris M, Gondar, Ethiopia; Adu-Bonsaffoh K, Accra, Ghana; Alnaes-Katjavivi P, Oslo, Norway; Ameh CA, Liverpool, UK; Berhane G, Korem, Ethiopia; Cavaliere E,Verona, Italy; Cecatti CJ, Campinas, Brazil; Chama C, Maiduguri, Nigeria; Compaore GD, Bobo-Dioulasso, Burkina Faso; De Brouwere V, Antwerp, Belgium; Essen B, Uppsala, Sweden; Etuk SJ, Calabar, Nigeria; Filippi V, London, UK; Ganaba R, Bobo-Dioulasso, Burkina Faso; Gessessew A, Mekele, Ethiopia; Getachew A, Malawi; Goufodji S, Cotonou, Benin; Gurgel RQ, Sergipe, Brazil; Haddad SM, Campinas, Brazil; Heitkamp A, Cape Town, South Africa; Kaye DK, Kampala, Uganda; Kidanto HL, Dar es Salaam, Tanzania; Knight M, Oxford, UK; Litorp H, Uppsala, Sweden; Lule J, Kampala, Uganda; Mantel G, Zwolle, the Netherlands; Meguid T, Zanzibar, Tanzania; Mohammadi S, Uppsala, Sweden; Nyamtema A, Ifakara, Tanzania; Okong P, Kampala, Uganda; Oladapo OT, Geneva, Switzerland; Osman N, Maputo, Mozambique; Pattinson RC, Pretoria, South Africa; Qureshi Z, Nairobi, Kenya; Rulisa S, Kigali, Rwanda; Soma-Pillay P, Pretoria, South Africa; Sombie I, Obo-Dioulasso, Burkina Faso; Souza JP, Geneva, Switzerland; Spector J, Boston, USA; Stekelenburg J, Leeuwarden, the Netherlands; Sule-odu AO, Sagamu, Nigeria; Theron G, Cape Town, South Africa; van den Akker T, Leiden, the Netherlands; van Raaij F, MST, the Netherlands; van Roosmalen J, Amsterdam, the Netherlands; Versluis M, Groningen, the Netherlands; Zwart JJ, Deventer, the Netherlands).

\section{Funding}

AKT received funding from the Netherlands Organisation for International Cooperation in Higher Education (NUFFIC) in the form of PhD grant in University of Groningen, University Medical Centre Groningen, the Netherlands. The funding organization has no role in the design, execution or decision to publish the manuscript.

\section{Availability of data and materials}

All data used for conclusion in this study are included in this article. Additional data are available from the corresponding author on reasonable request.

\section{Authors' contribution}

AKT, SAS, and JS conceived the study. AKT and SJG developed the questionnaire, collected data and analysed the data with continuous input from JS, SAS, TVdA, JvR, and JZ. AKT drafted a manuscript, which was revised by JS, SAS, JZ, TVdA, JvR, and SJG. All authors approved the final version for submission.

\section{Ethics approval and consent to participate}

This study was conducted as part of a PhD study on maternal near miss and maternal mortality in Ethiopia which was approved by the institutional health research ethics review committee of Haramaya University in Ethiopia (Ref No: C/A/R/D/01/1681/16). This study does not include any patientrelated or otherwise sensitive information. Informed consent was requested from all experts and completing online questionnaire was considered as consent to participation.

\section{Consent for publication}

Not applicable

\section{Competing interests}

JVR is section editor for BMC Pregnancy and Childbirth. The authors declare that they have no competing interests.

\section{Publisher's Note}

Springer Nature remains neutral with regard to jurisdictional claims in published maps and institutional affiliations.

\section{Author details}

'School of Nursing and Midwifery, College of Health and Medical Sciences, Haramaya University, Harar, Ethiopia. ${ }^{2}$ Department of Obstetrics and Gynaecology (CB20), University of Groningen, University Medical Centre Groningen, Hanzeplein 1, 9700 RB Groningen, Netherlands. ${ }^{3}$ Department of Health Sciences, Global Health, University of Groningen, University Medical Centre Groningen, Groningen, the Netherlands. ${ }^{4}$ Department of Obstetrics and Gynaecology, Leeuwarden Medical Centre, Leeuwarden, the Netherlands. ${ }^{5}$ Department of Obstetrics and Gynaecology, Deventer Ziekenhuis, Deventer, the Netherlands. ${ }^{6}$ Department of Obstetrics, Leiden University Medical Centre, Leiden, the Netherlands. ${ }^{7}$ Athena Institute, VU University Amsterdam, Amsterdam, the Netherlands.

Received: 21 July 2017 Accepted: 19 December 2017

Published online: 29 December 2017

\section{References}

1. World Health Organization. Beyond the numbers: reviewing maternal deaths and complications to make pregnancy safer. Geneva: World Health Organization; 2004.

2. Firoz T, Chou D, von Dadelszen P, Agrawal P, Vanderkruik R, Tuncalp O, et al. Measuring maternal health: focus on maternal morbidity. Bull World Health Organ. 2013;91(10):794-6.

3. World Health Organization. Evaluating the quality of Care for Severe Pregnancy Complications: the who near-miss approach for maternal health. Geneva: World Health Organization; 2011.

4. Mantel GD, Buchmann E, Rees H, Pattinson RC. Severe acute maternal morbidity: a pilot study of a definition for a near-miss. Br J Obstet Gynaecol. 1998;105(9):985-90.

5. Waterstone M, Bewley S, Wolfe C. Incidence and predictors of severe obstetric morbidity: case-control study. BMJ. 2001;322(7294):1089-93. discussion 1093-4

6. Say L, Souza JP, Pattinson RC. WHO working group on maternal mortality and morbidity classifications. Maternal near miss-towards a standard tool for monitoring quality of maternal health care. Best Pract Res Clin Obstet Gynaecol. 2009;23(3):287-96.

7. Nelissen EJ, Mduma E, Ersdal HL, Evjen-Olsen B, van Roosmalen JJ, Stekelenburg J. Maternal near miss and mortality in a rural referral hospital in northern Tanzania: a cross-sectional study. BMC Pregnancy Childbirth. 2013;13:141

8. Litorp H, Kidanto HL, Roost M, Abeid M, Nystrom L, Essen B. Maternal nearmiss and death and their association with caesarean section complications: a cross-sectional study at a university hospital and a regional hospital in Tanzania. BMC Pregnancy Childbirth. 2014;14:244-2393-14-244.

9. Rulisa S, Umuziranenge I, Small M, van Roosmalen J. Maternal near miss and mortality in a tertiary care hospital in Rwanda. BMC Pregnancy Childbirth. 2015;15:203-015-0619-8.

10. Oladapo O, Adetoro O, Ekele B, Chama C, Etuk S, Aboyeji A, et al. When getting there is not enough: a nationwide cross-sectional study of 998 maternal deaths and 1451 near-misses in public tertiary hospitals in a lowincome country. BJOG Int J Obstet Gynaecol. 2016;123(6):928-38. 
11. Nelissen E, Mduma E, Broerse J, Ersdal H, Evjen-Olsen B, van Roosmalen J, et al. Applicability of the WHO maternal near miss criteria in a low-resource setting. PLoS One. 2013;8(4):e61248.

12. van den Akker T, Beltman J, Leyten J, Mwagomba B, Meguid T, Stekelenburg J, et al. The WHO maternal near miss approach: consequences at Malawian District level. PLoS One. 2013;8(1):e54805.

13. Spector J. Practical criteria for maternal near miss needed for low-income settings. Lancet 2013;382(9891):504-505.

14. Souza JP, Say L, Gulmezoglu M. Practical criteria for maternal near miss needed for low-income settings - Authors' reply. Lancet. 2013;382(9891): 505-6736(13)61711-0.

15. Kalisa R, Rulisa S, van den Akker T, van Roosmalen J. Maternal near miss and quality of care in a rural Rwandan hospital. BMC Pregnancy and Childbirth. 2016;16:324.

16. Hsu C, Sandford BA. The Delphi technique: making sense of consensus. Practical assessment, research \& evaluation. 2007;12(10):1-8.

17. Al Wattar B, Tamilselvan K, Khan R, Kelso A, Sinha A, Pirie A, et al, Development of a CORE outcome set for epilepsy in pregnancy (E-CORE): a national multi-stakeholder modified Delphi consensus study. BJOG Int J Obstet Gynaecol. 2017;124(4):661-7.

18. Gordijn SJ, Beune IM, Thilaganathan B, Papageorghiou A, Baschat AA, Baker PN, et al. Consensus definition of fetal growth restriction: a Delphi procedure. Ultrasound Obstet Gynecol. 2016:48(3):333-9.

19. van 't Hooft J, Duffy JM, Daly M, Williamson PR, Meher S, Thom E, et al. A Core outcome set for evaluation of interventions to prevent preterm birth. Obstet Gynecol. 2016;127(1):49-58.

20. Rogozinska E, D'Amico MI, Khan KS, Cecatti JG, Teede H, Yeo S, et al. Development of composite outcomes for individual patient data (IPD) meta-analysis on the effects of diet and lifestyle in pregnancy: a Delphi survey. BJOG. 2016;123(2):190-8.

21. Keeney S, Hasson F, McKenna H. The Delphi technique in nursing and health research. John Wiley \& Sons; 2010. doi:10.1002/9781444392029.

22. Asselin M, Harper M. Revisiting the Delphi technique: implications for nursing professional development. J Nurses Prof Dev. 2014;30(1):11-5.

23. Kennedy HP. Enhancing Delphi research: methods and results. J Adv Nurs. 2004:45(5):504-11.

24. Wielenga JM, Tume LN, Latour JM, van den Hoogen A. European neonatal intensive care nursing research priorities: an e-Delphi study. Arch Dis Child Fetal Neonatal Ed. 2015;100(1):F66-71.

25. Tura, AK. Gebrehiwo,Y. Zwart,JJ. van Roosmalen, J. Stekelenburg, J. Scherjon,S. Systematic review of severe acute maternal morbidity (near miss) in sub-Saharan Africa: implications for the post-millennium development goals era. 2015; Available at: http://www.crd.york.ac.uk/ PROSPERO/display_record.asp?ID=CRD42015023883.

26. Filippi V, Ronsmans C, Gohou V, Goufodji S, Lardi M, Sahel A, et al. Maternity wards or emergency obstetric rooms? Incidence of near-miss events in African hospitals. Acta Obstet Gynecol Scand. 2005;84(1):11-6.

27. Diamond IR, Grant RC, Feldman BM, Pencharz PB, Ling SC, Moore AM, et al. Defining consensus: a systematic review recommends methodologic criteria for reporting of Delphi studies. J Clin Epidemiol. 2014;67(4):401-9.

28. Okoli C, Pawlowski SD. The Delphi method as a research tool: an example, design considerations and applications. Information \& Management. 2004; 42(1):15-29.

29. De Mucio B, Abalos E, Cuesta C, Carroli G, Serruya S, Giordano D, et al. Maternal near miss and predictive ability of potentially life-threatening conditions at selected maternity hospitals in Latin America. Reprod Health. 2016;13(1):134

30. van den Akker T, van Rhenen J, Mwagomba B, Lommerse K, Vinkhumbo S, van Roosmalen J. Reduction of severe acute maternal morbidity and maternal mortality in Thyolo District, Malawi: the impact of obstetric audit. PLoS One. 2011;6(6):e20776.

31. Strand RT, Tumba P, Niekowal J, Bergstrom S. Audit of cases with uterine rupture: a process indicator of quality of obstetric care in Angola. Afr J Reprod Health. 2010;14(2):55-62.

32. Bates I, Chapotera GK, McKew S, van den Broek N. Maternal mortality in sub-Saharan Africa: the contribution of ineffective blood transfusion services. BJOG. 2008;115(11):1331-9.

33. Lobato G, Nakamura-Pereira M, Mendes-Silva W, Dias MA, Reichenheim ME. Comparing different diagnostic approaches to severe maternal morbidity and near-miss: a pilot study in a Brazilian tertiary hospital. Eur J Obstet Gynecol Reprod Biol. 2013;167(1):24-8.
34. Witteveen T, Bezstarosti $H$, de Koning I, Nelissen E, Bloemenkamp KW van Roosmalen J, et al. Validating the WHO maternal near miss tool: comparing high- and low-resource settings. BMC Pregnancy Childbirth. 2017;17(1):194. -017-1370-0

35. Khan K. Chief editors of journals participating in the CROWN initiative (appendix 1). The CROWN initiative: journal editors invite researchers to develop core outcomes in women's health. BJOG. 2016;123(Suppl 3):103-4.

\section{Submit your next manuscript to BioMed Central and we will help you at every step:}

- We accept pre-submission inquiries

- Our selector tool helps you to find the most relevant journal

- We provide round the clock customer support

- Convenient online submission

- Thorough peer review

- Inclusion in PubMed and all major indexing services

- Maximum visibility for your research

Submit your manuscript at www.biomedcentral.com/submit 